\title{
Analysis of interlingual and intralingual interferences found in writings of efl learners at UTA.
}

Análisis de las interferencias interlinguales e intralingües encontradas en los escritos de efl learners en UTA.

Wilber Romero Villarroel. ${ }^{1} \&$ Sara Camacho Estrada. ${ }^{2}$

\begin{abstract}
.
DOI: https://doi.org/10.33262/cienciadigital.v9i2.380

In a non-English speaking country, committing errors when writing is an evidence that the learner's native language system is confronting the target language system. This study aims at investigating the type and source of writing errors committed by Elementary A2 EFL learners at the Technical University of Ambato. The data of study were a total of 170 writings distributed in five different types of narratives (1) "Describing Past Experiences", 2) "Describing a favorite place", 3) "Describing someone special", 4) "Describing preferences", and 5) "Describing plans for the Future"). The method used to process the information was based on Gass \& Selinker (2008) model. The results of the study showed that most of the errors made by second language learners are largely due to intralingual interferences in the form of omissions and substitutions. Learners' language developmental factors outweigh interlingual transfers and are represented by omissions and substitutions errors. On the other hand, interlingual transfers denote the presence of lexico-semantic and morpho-syntactic elements of learner's L1.
\end{abstract}

Keywords: Writing, Interference, Interlingual Errors, Intralingual Errors, Narratives

1 Universidad Técnica de Ambato, Ambato, Ecuador wo.romero@uta.edu.ec

2 Universidad Técnica de Ambato, Ambato, Ecuador, scamacho@uta.edu.ec 


\section{Resumen.}

En un país que no posee el idioma inglés como lengua nativa, el cometer errores al escribir es una evidencia de que el sistema de idioma nativo del estudiante se confronta al sistema de idioma de destino. Este estudio tiene como objetivo investigar el tipo y la fuente de los errores de escritura cometidos por los estudiantes de nivel elemental A2 de Inglés como Lengua Extranjera en la Universidad Técnica de Ambato. Los datos de estudio fueron un total de 170 escritos distribuidos en cinco tipos diferentes de narrativas (1) " Descripción de experiencias pasadas", 2) "Descripción de un lugar favorito", 3) " Descripción de alguien especial", 4) " Descripción de preferencias", y 5) "Descripción de planes para el futuro"). El método utilizado para procesar la información se basó en el modelo de Gass \& Selinker (2008). Los resultados del estudio mostraron que la mayoría de los errores cometidos por estudiantes de segundo idioma se deben en gran parte a interferencias de tipo intralingüísticas en forma de omisiones y substituciones. Los factores relacionados al desarrollo del lenguaje de los estudiantes superan en número a las transferencias interlingüísticas y están representados por omisiones y errores de sustitución. Por otro lado, las transferencias interlingüísticas denotan la presencia de elementos de tipo léxico-semánticos y morfosintácticos propios del L1 del estudiante.

Palabras claves: Escritura en inglés, Interferencia, Errores Interlingüísticos, Errores Intralingüísticos, Narrativa

\section{Introducción.}

At university level, the development of English writing has become of paramount importance. Written production is one of the competences that students have to develop. Being able to communicate in a written way is crucial for academic success. However, during the process of developing this skill, students unavoidably commit errors which result in the learner using and learning the language incorrectly. Behla (1999) states that language learners develop individual items of target language but demonstrates difficulty in organizing this knowledge into appropriate, coherent structures. Initially, language pedagogy tried to prevent students from making errors when learning. But what does it take for a learner to notice that making mistakes is an opportunity to learn? It is now believed that making errors may actually help learners learning when they self-correct the errors they make (Ellis,1999, p.15). Selinker (1969) as cited in Touchie (1986) remarks that errors are significant due to three reasons. First, they indicate learner's progress in language learning; second, errors provide insights into how language is learnt; third, errors help learners in getting involved in hypothesis testing. Language learners at the Technical University of Ambato are not the exception. At elementary level learners are constantly trying out their written skills and of course this process of learning a language implies committing countless errors. These errors are usually analyzed and categorized according to source. Reid (1993) recognizes errors as 
"language interferences". Likewise, Richards (1971) distinguishes the presence of "Interlanguage Errors", "Intralingual and Developmental Errors".

In the learning process, learners are not aware they are committing errors. Regarding to the nature of errors, Gass and Selinker (1994) state that L1 language learning process is not different to the L2 learning. Learners cannot avoid committing errors just like when they are learning their L1. Identifying a particular error type may result into an easy task, however finding its roots requires a deeper understanding of the context, cultural background and students type. This study is important because it reveals the learners most significant error types that systematically interfere when writing in English. Interlingual and Intralingual interferences remain as the most influential elements of language interference. Such findings are of great value for instructors and learners as it provides significant information for teaching and learning awareness.

\section{Literature Review.}

\section{Notions of Language Interference}

The role of errors in a learner's written production is of great importance as it serves as an evidence that a learner is confronting his own metacognition of language to learn another language. In this confrontation of structures to construct meaning, intervene aspects of the learner's linguistic competence. Research has shown that this interference of language aspects favor and sometimes prevents communication. Milroy and Wei (1995) state that language interference is a practice which is governed by grammatical principles, environmental, social and personal influences. Ellis (1997) as cited in Deepa, et all (2009) refers the term interference as "transfer" and argues that learner's perceptions govern what is transferable. In foreign language writing, students are prone to transfer their own language system into the new language being learnt. With this basis, interference occur due to habit of the surface structure of the first language onto the surface of the target language (Dulay et all, 1982, p. 98).

\section{Interlingual Errors}

Richards (1971) refers to these type of errors as 'Interlanguage Errors" which are normally caused by the interference of learner's mother tongue over the target language. This study will use the term "Interlingual errors" used by Selinker (1988) who cited Weinreich (1953, p. 7) referring to the interferences ("identifications") used by individuals in a language contact situation. The mental schema under which the learner's ideas are arranged, influence the different aspects of language production. Corder (1981) calls this mental schema as habits that prevent the learner from acquiring the new patterns or rules of the target language.

\section{Intralingual Errors}


Another typical source of errors that can affect written performance of a learner is known as intralingual or developmental errors. Richards (1971) defines that these type of errors demonstrate some general characteristics of language acquisition but reflect a certain level of language competence. This idea denotes that even when the learner makes errors, there is some type of cognitive process going on in his head. On the other hand, according to Mahmoud (2011) these derive from the learner's lack of competence in the language. This view is away from Richard's, as the focus is more on weaknesses from the part of the learner regarding commanding grammar aspects. Similarly, for Touchie (1986) competence errors are more serious because they reflect inadequate learning. Blurt and Kiparsky (1974) as cited in Touchie (1986), defines developmental errors as those that "interfere with communication and disrupts the meaning of utterances" However, research has also demonstrated that "it might be difficult to differentiate performance deviations from those that are due to the lack of competence in the language as an error may turn out to be a vocabulary error and vice versa, and an error could be interlingual or intralingual" (Mahmoud, 2011, p.32).

\section{Types of Intralingual interferences}

There is a very important number of classifications of errors made by well recognized scholars which range from grammatical perspectives of the language to linguistic and pragmatic relationships of the use of language. For example Touchie (1986) distinguishes the following types: 1) Simplification, 2) Overgeneralization, 3) Hypercorrections, 4) Faulty Teaching, 5) Fossilization, Avoidance, 6) Inadequate Learning and 7) False Concept Hypothesized.

A very interesting approach to classifying error is made from Richards (1971) in his paper "A non-contrastive Approach to Error Analysis" where his view of errors distinguishes 3 types: 1) Faulty Generalization Errors, 2) Incomplete Application of Rules Errors, 3) Failure to learn conditions under which rules apply.

This study used only two aspects of the linguistic Based classification made by Keshavarz (2012) regarding to Lexico-semantic Errors and Morphological-Syntactic Errors and the taxonomy represented in the Process-based classification of errors suggested by Brown (2000) which are Omissions, Additions, Substitutions and Permutations. These last four are closely related to the classification structured by Dulay et al as cited in Gayo, H., \& Widodo, P. (2018) who name surface structure errors in Morpheme and syntax levels categorized in Omission, Addition, Misformation and Disordering.

\section{Method}

\section{Participants}


The participants for this study were 34 learners of Elementary 2A English level at the Technical University of Ambato. Students range in ages between 18 and 21 years old.

\section{Materials}

The research material for this study were 170 written compositions gotten from the 34 Elementary English level learners. The narrative type for the compositions were: 1) "Describing Past Experiences", 2) "Describing a favorite place", 3) "Describing someone special", 4) "Describing preferences", and 5) "Describing plans for the Future". Each of the narratives responded to a grammar structure study stage which compelled learners to use a particular tense and appropriate command of vocabulary.

It was necessary to investigate the different linguistic classifications of error, and for this, the classification given by Keshavarz (2012) and the one suggested by Brown (2000), served to stablish the appropriate classification according to the type of written work and process of analysis for it. These two classifications helped to organize learners' writing errors.

Table 1.- Code System to Identify student's errors in written production.

\begin{tabular}{|l|l|c|}
\hline Code & \multicolumn{1}{|c|}{ Code Meaning } & Number of Cases \\
\hline$? ? ?:$ & $\begin{array}{l}\text { Lexico semantic } \\
\text { error }\end{array}$ & \\
\hline$\#$ & $\begin{array}{l}\text { wrong use of plural } \\
\text { morpheme. }\end{array}$ & \\
\hline $\mathrm{Vt}$ & $\begin{array}{l}\text { Wrong use of } \\
\text { tenses. }\end{array}$ & \\
\hline $\mathrm{Wo}$ & wrong word order & \\
\hline $\mathrm{Wp}$ & $\begin{array}{l}\text { Wrong use of } \\
\text { prepositions. }\end{array}$ & \\
\hline $\mathrm{Wa}$ & $\begin{array}{l}\text { Errors in the use of } \\
\text { articles. }\end{array}$ & \\
\hline$\Lambda$ & Omission: & \\
\hline & Addition: & \\
\hline $\mathrm{WW}$ & Substitution: & \\
\hline & Permutation: & \\
\hline & TOTAL & \\
\hline
\end{tabular}

Prepared by: Research Group. 


\section{Procedure}

The methodology used to organize data followed the steps proposed by Gass \& Selinker (2008): 1.- Collect Data; 2.- Identify Errors; 3.- Classify Errors; 4.- Quantify Errors; 5.Analyze Source. The process demanded a content analysis considering searching the presence of errors at word use level and grammatical structures.

In order to collect data, Students were asked to write five types of narratives at different times of the school period. The writing tasks were requested according to the Unit and grammar focus developed in the lesson. Each learner had to develop the topic given in approximately 100 words. Right after that the teacher collected them and used a writings error code guide for the identification of the errors. This helped to identify the type of errors committed during the writing process. Afterwards, the information (errors) was sorted out and counted into an error type classification code table.

Later on, a matrix for classifying Interlingual and Intralingual errors was made. This matrix gathered the total number of occurrences, percentage and source of errors that the error type classification code table provided per narrative and error type. Finally, in order to sum up the findings, all the numerical and percent results were registered in a final matrix which displayed the interlingual and intralingual total interferences in each narrative type.

For the error source analysis, it was necessary to turn to specialized literature about the types and sources of error found in writings. Specific factors related to negative transfer accounted for the appearance of Lexico-semantic, morphological and process based elements.

\section{RESULTS (Data Analysis)}

The analysis of the compositions gave the following results: (The following tables 2-3, were taken from a research study made from Sari (2012) on interlingual and intralingual errors). 
Table 2: Identification of linguistic interferences found in the five narrative types.

\begin{tabular}{|c|c|c|c|c|c|c|c|c|c|c|c|c|}
\hline \multirow{2}{*}{ No } & \multirow{2}{*}{$\begin{array}{l}\text { Types of } \\
\text { Interlingual } \\
\text { Errors and } \\
\text { Intralingual } \\
\text { Errors }\end{array}$} & \multicolumn{2}{|c|}{$\begin{array}{c}\text { PAST } \\
\text { EXPERIENCES }\end{array}$} & \multicolumn{2}{|c|}{$\begin{array}{c}\text { DESCRIBING } \\
\text { A FAVORITE } \\
\text { PLACE }\end{array}$} & \multicolumn{2}{|c|}{$\begin{array}{l}\text { DESCRIBING } \\
\text { SOMEONE } \\
\text { SPECIAL }\end{array}$} & \multicolumn{2}{|c|}{$\begin{array}{l}\text { EXPRESSING } \\
\text { PREFERENCES }\end{array}$} & \multicolumn{2}{|c|}{$\begin{array}{l}\text { PLANS } \\
\text { FOR THE } \\
\text { FUTURE }\end{array}$} & \multirow[b]{2}{*}{$\begin{array}{l}\text { Source of } \\
\text { Error }\end{array}$} \\
\hline & & $\mathbf{f}$ & $\%$ & f & $\%$ & $\mathbf{f}$ & $\%$ & $\mathbf{f}$ & $\%$ & f & $\%$ & \\
\hline & $\begin{array}{l}\text { INTERLINGUAL } \\
\text { ERRORS }\end{array}$ & & & & & & & & & & & \\
\hline \multirow[t]{2}{*}{1} & $\begin{array}{l}\text { Lexico-Semantic } \\
\text { Errors }\end{array}$ & 23 & $19.16 \%$ & 12 & $8.33 \%$ & 69 & $8.67 \%$ & 15 & $9.80 \%$ & 58 & $17.52 \%$ & $\begin{array}{l}\text { Transfer of } \\
\text { Lexico- } \\
\text { semantic } \\
\text { elements }\end{array}$ \\
\hline & $\begin{array}{l}\text { Morphological- } \\
\text { Syntactic Errors }\end{array}$ & & & & & & & & & & & $\begin{array}{l}\text { Transfer of } \\
\text { morphological } \\
\text { elements }\end{array}$ \\
\hline 2 & $\begin{array}{l}\text { Wrong use of plural } \\
\text { morpheme }\end{array}$ & 7 & $5.83 \%$ & 6 & $4.2 \%$ & 3 & $1.36 \%$ & 3 & $1.96 \%$ & 1 & $0.30 \%$ & $\begin{array}{l}\text { Transfer of } \\
\text { Grammatical } \\
\text { elements }\end{array}$ \\
\hline 3 & $\begin{array}{lll}\text { Wrong use of } \\
\text { Tenses }\end{array}$ & 11 & $9.16 \%$ & 2 & $1.38 \%$ & 12 & $5.47 \%$ & 4 & $2.61 \%$ & 16 & $4.83 \%$ & \\
\hline 4 & Wrong word order & - & - & - & - & - & - & 1 & $0.65 \%$ & - & - & \\
\hline 5 & $\begin{array}{l}\text { Wrong use of } \\
\text { prepositions }\end{array}$ & 5 & $4.16 \%$ & 7 & $4.86 \%$ & 3 & $1.36 \%$ & 5 & $3.26 \%$ & 7 & $2.11 \%$ & \\
\hline \multirow[t]{2}{*}{6} & $\begin{array}{l}\text { Errors in the use of } \\
\text { articles. }\end{array}$ & 1 & $0.83 \%$ & - & - & 1 & $0.45 \%$ & 3 & $1.96 \%$ & - & - & \\
\hline & $\begin{array}{l}\text { INTRALINGUAL } \\
\text { ERRORS }\end{array}$ & & & & & & & & & & & \\
\hline 7 & Omission & 35 & $29.16 \%$ & 37 & $25.69 \%$ & 67 & $30.59 \%$ & 64 & $41.83 \%$ & 136 & $41.08 \%$ & $\begin{array}{l}\text { Developmental } \\
\text { factors }\end{array}$ \\
\hline 8 & Addition & 12 & $10 \%$ & 26 & $18.05 \%$ & 20 & $9.13 \%$ & 24 & $15.68 \%$ & 33 & $9.96 \%$ & \\
\hline 9 & Substitution & 17 & $14.16 \%$ & 44 & $30.55 \%$ & 36 & $16.43 \%$ & 33 & $21.56 \%$ & 72 & $21.75 \%$ & \\
\hline \multirow[t]{2}{*}{10} & Permutation & 9 & $7.5 \%$ & 10 & $6.94 \%$ & 8 & $3.65 \%$ & 1 & $0.65 \%$ & 8 & $2.41 \%$ & \\
\hline & TOTAL & 120 & $100 \%$ & 144 & $100 \%$ & 219 & $100 \%$ & 153 & $100 \%$ & 331 & $100 \%$ & \\
\hline
\end{tabular}

Prepared by: Research Group.

f: $\quad$ number of cases / ocurrences.

$\%$ : percentage of cases / ocurrences

The present table shows that an important number of errors are caused by interlingual errors. Learners tend to commit more errors in the Lexico-semantic aspect ( 58 cases $=17.52 \%$ ). Learners' mother tongue played a great influence in meaning and word choice. Generally, grammatical and word choice transfers take place during this process.

Conversely, the results evidenced that the highest number of errors are of intralingual type. These errors took the form of omissions $(136$ cases $=41.08 \%)$ because, as it can be seen in the error samples provided later on, learners tend to constantly omit personal pronouns, suffixes and verb forms. The same thing occurred with addition (33 cases $=9.96 \%$ ) and substitution errors ( 72 cases $=21.75 \%$ ). This is due to learners' limited knowledge of 
grammar rules which go beyond their present learning stage. Regarding the other areas described, learners commit minor errors.

Table 3: Total Interlingual and Intralingual Errors Frequencies found in 5 sources of Students written works.

\begin{tabular}{|c|c|c|c|c|c|c|c|c|c|c|}
\hline \multirow[t]{2}{*}{$\begin{array}{l}\text { Types of } \\
\text { Errors }\end{array}$} & \multicolumn{2}{|c|}{$\begin{array}{c}\text { PAST } \\
\text { EXPERIENCES }\end{array}$} & \multicolumn{2}{|c|}{$\begin{array}{c}\text { DESCRIBING A } \\
\text { FAVORITE PLACE }\end{array}$} & \multicolumn{2}{|c|}{$\begin{array}{c}\text { DESCRIBING } \\
\text { SOMEONE } \\
\text { SPECIAL } \\
\end{array}$} & \multicolumn{2}{|c|}{$\begin{array}{l}\text { EXPRESSING } \\
\text { PREFERENCES }\end{array}$} & \multicolumn{2}{|c|}{$\begin{array}{l}\text { PLANS FOR THE } \\
\text { FUTURE }\end{array}$} \\
\hline & Cases & Percentage & Cases & Percentage & Cases & Percentage & Cases & Percentage & Cases & Percentage \\
\hline Interlingual & 47 & $39.16 \%$ & 27 & $18.75 \%$ & 88 & $40.18 \%$ & 31 & $20.26 \%$ & 82 & $24.77 \%$ \\
\hline Intralingual & 73 & $60.83 \%$ & 117 & $81.25 \%$ & 131 & $59.81 \%$ & 122 & $79.73 \%$ & 249 & $75.22 \%$ \\
\hline Total & 120 & $100 \%$ & 144 & $100 \%$ & 219 & $100 \%$ & 153 & $100 \%$ & 331 & $100 \%$ \\
\hline
\end{tabular}

Prepared by: Research Group.

As it can be seen from table 3, there is a meaningful difference in the number of error cases between interlingual and intralingual interferences per narrative. In general, intralingual interferences outnumber interlingual errors. The narrative "Plans for the Future" and "Describing someone special" denote the highest number of cases in the two types of interferences.

Figure 1: Frequencies of Interlingual and Intralingual Errors found in 5 sources of Students written compositions.

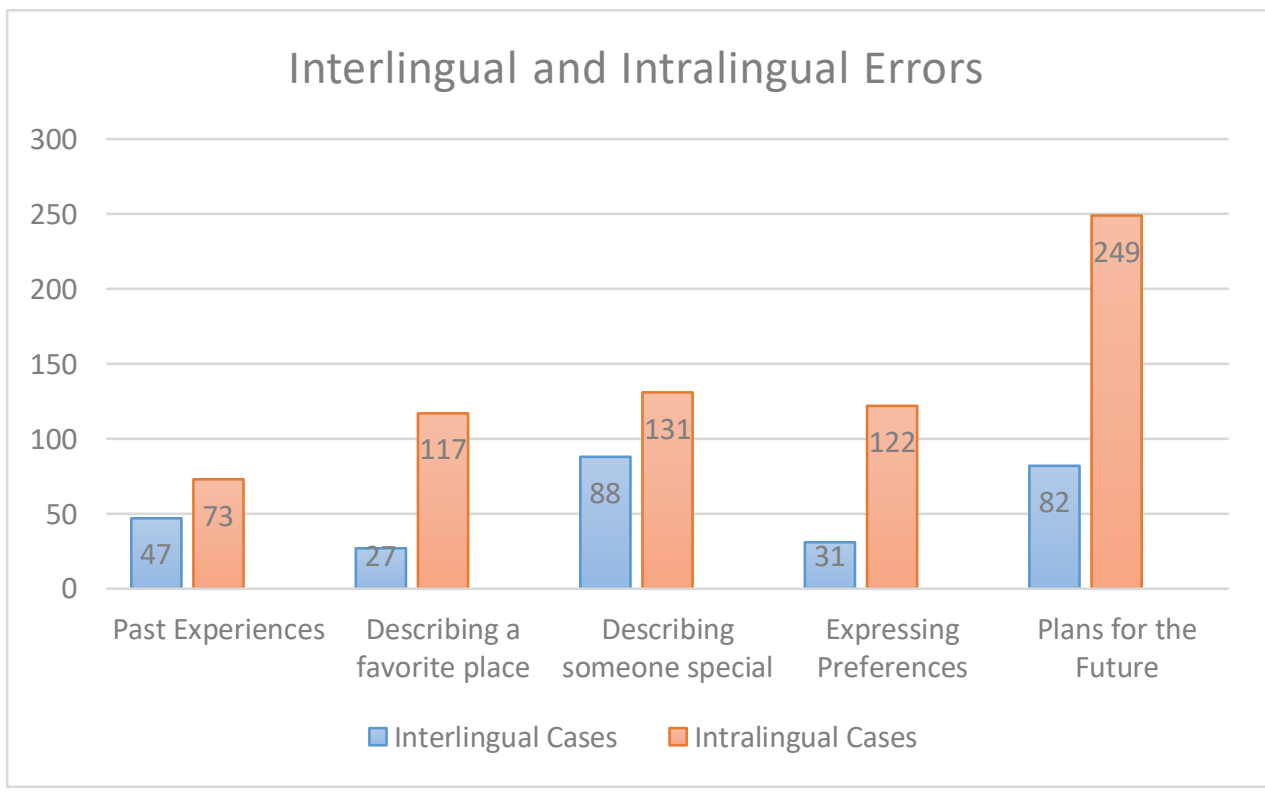

Prepared by: Research Group.

This figure shows the global results of the research. Errors are categorized into interlingual and intralingual types. As it can be seen, the figure shows a higher number of occurrences in 
the Intralingual type of errors in the five types of narratives. On the other hand, Interlingual interferences are fewer compared to the intralingual errors.

\section{Samples of Interlingual Errors taken from the learners' writings. Lexico Semantic Errors}

Lexico semantics has to do with the study of word meaning and its relationship with other words in sentences (Geeraerts, 2017). Lexico semantic interferences are errors that happen when the meaning system of a word is imposed over the target language system Fellbaum, C., \& Pustejovsky, J. (1997). For the learner, this confusion arises from the identification of equivalences or word aspects like the phonetics resembles to another word in the target language. Among others, one of the most systematic errors type is false friends. These are referred as borrowings which are transferred from the L1 into the L2.

- We can practice some extreme sports with for example, canopy, cycling.

- I went to the place where stayed the man.

- I never come inside him.

- When my mother had 17 years old...

\section{Morphological-Syntactic Errors.}

As morpho-syntaxis as a field of linguistics focuses on the study of the form and functions of words within a sentence, it is quite normal for learners to make errors at this level. The present study demonstrated interferences that denote interferences mostly in wrong use of tenses, word order, pluralization, and use of articles. This is the result of mother tongue interference

- The system transportation in my town is "trole bus".

- First I going sightseeing place.

- I thought about leave with our friends

- On my last vacation we stay in "Marbella"hotel.

\section{Samples of Intralingual Errors.}

\section{Omission.}

An omission is a type of Intralingual error which denotes the absence of an item of a word. It disharmonizes a coherent meaning within a sentence. Learners tend to leave out important elements which directly affect syntax in a sentence.

- I felt nervous but ${ }^{\downarrow}$ jump without think twice.

- I liked hornado because ${ }^{\downarrow}$ was very delicious. 
- We went to Guayaquil to see how ${ }^{\star}$ make the serum for snake bites.

- One of my favorite place is "La Moya".

\section{Addition.}

Sometimes learners tend to unnecessarily add other items or element in a sentence which make them sound redundant. These type of errors are called addition errors.

- The people live around of the lake.

- There are lots of bigs and littles restaurants and cafes.

- It is near to Ambato.

- I live in Pelileo city.

\section{Substitution.}

As shown in tables 2 and 3, substitution errors represent an important number. The researcher found out that due to the limited knowledge learners have about the target language rules and word usage, it prevents them from conveying accurate meaning in sentences.

- In this place you can walk and take photos with your family.

- You can see local animals how: jaguar, snakes, caiman etc.

- I feel something walking for my face.

- My father is a taxi driver. Your job is very tired.

- I don't job because I study at the university.

\section{Permutation.}

Permutation is a process of analysis mostly used in mathematics. In the field of linguistics, it consists on the act of altering or misordering the order of a group of words in a sentence. Spanish mother tongue speakers tend to transfer L1 word order into L2.

- My favorite place is the house the my grandmother.

- In this place live my grandfather.

- It is a place very beautiful and comfortable.

- Always we wait for my brother.

- I am going to eat food traditional.

\section{Conclusions.}

- This study aimed to identify and analyze the interlingual and intralingual errors made by EFL learners when writing in English. It revealed a wide variety of cases and occurrences which were classified and analyzed accordingly. These findings helped 
to support the response to the research questions. Do learners commit more interlingual or intralingual errors? What kinds of narratives present a higher percentage of errors?

- Data collected confirmed that the type of errors UTA university students have are characterized with a heavy intralingual load. Omissions and substitutions errors are the most frequent. Omissions of personal pronouns before verbs and suffixes in word forms such as -ing or -ed verb endings denoted lack of language rules mastery. Substitutions indicated misuse of word choice. Use of wrong prepositions, nouns and adjectives were due to language developmental factors. Interlingual errors were also present but in a less percentage compared to intralingual errors. These mostly reflected transfer of Lexico-semantic and morpho-syntactic elements of L1.

- Referring to the second research question, in the five types of narratives developed by learners in class, it was evidenced that the narrative that shows the highest number of errors is "Plans for the future" (249 intralingual errors). Followed by "Describing someone special" (131 intralingual errors).

- Regarding further research, an interesting study would be to find out instructional approaches to get learners become aware of Language differences through error analysis. Learners' Metacognition development would give them chances to regulate their own language processing in order to recognize and avoid inter and intralingual errors beforehand.

\section{References Bibliographical.}

Bhela, B. (1999). Native language interference in learning a second language: Exploratory case studies of native language interference with target language usage. International Education Journal, 1(1), 22-31

Brown, H.D. (2007) Principles of Language Learning and Teaching. San Francisco: Longman centered EFL Vocabulary Instruction. Arab World English Journal, 2(3), $29-41$.

Corder, S. P. (1981) Error and Interlanguage. London: Oxford University.

Deepa, N., Avanthi, N., Abhishek, B., \& Shymala, C. (2009). Phonological, Grammatical and Lexical Interference in Adult Multilingual Speakers. Language In India, 9, 2.

Ellis, R. (1997) Second Language Acquisition, Oxford University Press, Oxford.

Fellbaum, C., \& Pustejovsky, J. (1997). The Generative Lexicon. Language, 73(3), 597. doi: $10.2307 / 415891$

Gayo, H., \& Widodo, P. (2018). An Analysis of Morphological and Syntactical Errors on the English Writing of Junior High School Indonesian Students. International Journal Of 
Learning, Teaching And Educational Research, 17(4), 58-70. doi: 10.26803/ijlter.17.4.4

Geeraerts, D. (2017). Lexical Semantics. Oxford Research Encyclopedia Of Linguistics. doi: 10.1093/acrefore/9780199384655.013.29 Journal, XXV(3), 204-219. doi: 10.1093/elt/xxv.3.2041

Mahmoud, A. (2011). The Role of Interlingual and Intralingual Transfer in Learner

Reid, J. M. (1993). Teaching ESL writing. NJ: Prentice Hall Regents.

RICHARDS, J. (1971). A Non-Contrastive Approach to Error Analysis1. ELT

S. Gass, L. Slinker (1984) Second Language Acquisition: an Introductory Course LEA, Mahwah, NJ (1994)

Sari, E. (2016). Interlingual Errors and Intralingual Errors Found in Narrative Text Written by EFL Students in Lampung. Jurnal Penelitian Humaniora, 17(2), 87. doi: 10.23917/humaniora.v17i2.2501

Selinker, L. (1988). Papers in Interlanguage. Southeast Asian Ministers of Education Organization (Singapore). Regional Language Center, p, 30.

Touchie, H. (1986). Second Language Learning Errors Their Types, Causes, And Treatment. JALT Journal, 8(1), 75-80.

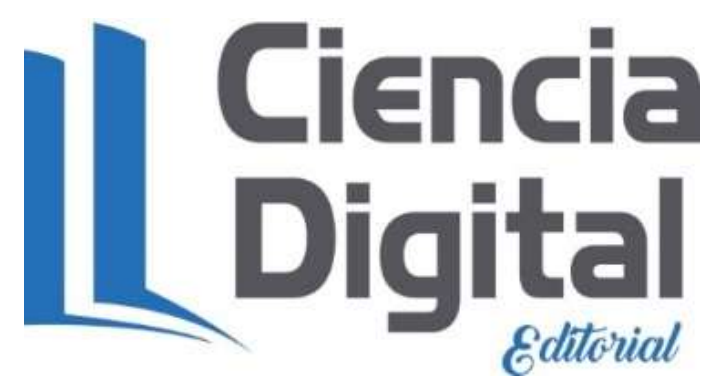




\section{Para citar el artículo indexado.}

Romero W. \& Camacho S. (2019). Analysis of interlingual and intralingual interferences found in writings of efl learners at UTA. Revista electrónica Ciencia Digital 3(2), 124-137. Recuperado desde: http://cienciadigital.org/revistacienciadigital2/index.php/CienciaDigital/article/view/380/828

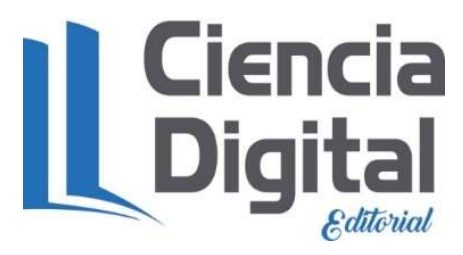

El artículo que se publica es de exclusiva responsabilidad de los autores y no necesariamente reflejan el pensamiento de la Revista Ciencia Digital.

El artículo queda en propiedad de la revista y, por tanto, su publicación parcial y/o total en otro medio tiene que ser autorizado por el director de la Revista Ciencia Digital.
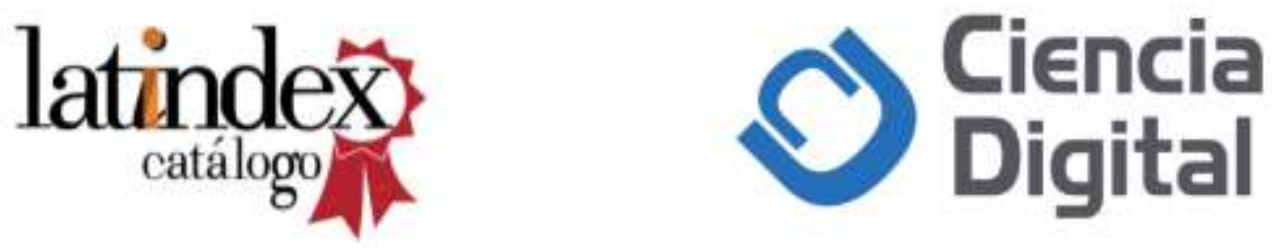